\title{
Islamic Management Perspective Of Human And Material Resources
}

\author{
RafiuWasiu Kehinde ${ }^{1} \&$ Ahmad Abdul Malik ${ }^{2}$ \\ ${ }^{I}$ Faculty of Leadership and Management, UniversitiSains Islam Malaysia \\ ${ }^{2}$ Faculty of Leadership and Management, UniversitiSains Islam Malaysia
}

\begin{abstract}
Islamic perspectiveon management has been described and discussed on the basis of the revealed sources of Islamic knowledge such as the holy Qur'an and Hadith. This is considered to be the valid instruments of contact or consult for the smooth running of human affairs. Currently, the management practices of some muslim dominated communities have turned otherwise in terms of human and material resources management. This led to the re-introduction of Islamic management theories in order to make case for models of Islamic management system which is expected to serve as a reminder and turning point for the Muslim leaders who have prioritized the western principles above the teachings of Islam on management of human and materials affairs. Our engagements in life, especially the muslims must be in line what has been ordained by Allah (swt)and the teachings of His most respected apostle Muhammad (pbuh), becausethis is the strategic way of decision making in Islamwhich requires God's consciousness. Researchers in this paper attempted to discuss benefits of Islamic management principles and theories above other theories of management of human and material resources.
\end{abstract}

Keywords: Islamic Management, Human, Material, Resources.

\section{Introduction}

Islam is not only a religion but a total way of human life, likewise management has been clearly regarded as actions in our daily life. This includes relationship with the social, economic and political life of the entire Muslim world in order to meet Allah (SWT) with a peaceful mind (QalbunSaleemun).

In Islamic Management, there are two major reference points to be considered as the source(s) of its generation, these are the holy Qur'an and Hadith, in these two, Islamic perspectives on management are described and discussed on the basis of the above revealed sources of Islamic knowledge, these two elements are considered to be valid instruments of contact or consult.Abbasi et al, (2010)[1] , indicated that; "muslim have to fully carry out in practice, the instructions given by prophet Muhammad (PBUH) as ordained by God". That is, every instruction given by Allah and His apostle must be properly followed to the letter, because men are strictly warned to be moderate and considerate in whatever they are doing in order not to cause hazard to their fellow human beings and the entire MuslimUmmah.

But despite the profound lessons and admonitions from Allah and His prophet concerning proper management, many people, Muslims inclusive have turned deaf ears to it, where, lack of accountability, lack of humility, irresponsibility, arrogancy as well as extravagancy have prevailed and become the order of the day.

The motive behind this paper is to look at management from both traditional and Islamic perspectives, in terms of relationship, differences as well as identifying the principles, functions and models of Islamic management as encouraged during the early period of Islam till the present time all over world.

\section{Objectives Of The Study}

- To enumerate the concepts of Islamic management as a moderate system of living.

- To compare Islamic management with that of conventional system ofmanagement.

- $\quad$ To highlight the models of Islamic Management.

- To appreciate the system of management beingimplemented in the early days of Islam.

\section{Research Questions}

- Does the concept of Islamic management encouragea moderate system of living?

- $\quad$ Are there any differences between Islamic and conventional systems of management?

- $\quad$ Are there any models for Islamic Management?

- Was there any system of managementbeing implemented in the early days of Islam? 


\section{Research Methodology}

Due to the qualitative nature of the study, the researcher hereby adopts the use of qualitative methods as well as descriptive method to carry out the research. The research will be majorly based on paper review to accessthe necessary information for better understanding of the subject matter.

\section{Management In Brief}

Literarily, management can be referred to asways of taking actions in every one's life, by implication, one cannot attain his or her goal(s) in life without management, actions such as decision, planning, organizing, application and evaluation are what could be totally considered as the acts of management.

But in a broader sense, the issue of management in an organisation has been defined in different ways by different authors, meaning that, there is no fixed or specific, time and circumstances which determined the management concept, these disparities generated a lot of controversy on its clear cut concept. Another aspect is that of its composition of arts and science, butdespite the fact that, art had been existing for long, before the arrival of science, the controversy was manifested that management is an art or science or both, in this regard, it is seen that, management has been recognised in two ways as the oldest of arts and youngest of science (AnupamKarmakar\&BidishaDatta 2012) [2].

This explains the dynamic nature of the word 'management'. For instance, management has been seen as a process of working with other people to accomplish organizational goals. (Alan B. A. 2006) [3].

Moreso, management concept is an aged and universal issue, where different views have surfaced concerning its natures by different scholars often and often, this continuous and fast transformation or development of management principles and practices in a given organization has affected its nature.

In this while, it is regarded as an act and science which is considered by the American Society of Engineers thus "management is an art as well as science of preparing, organizing and directing human efforts to control the forces and utilize the materials of nature for the benefit of men". Also in the work of Dean Stanley, quoted by Sanket, (2013), he agreed that "Management is a mixture of an art and science with the present ratio about $80 \%$ art and $20 \%$ science" (Sanket, K. 2013) [4]

\section{Islamic Management}

In a literal term, management in Islam can be referred to as an action in every one's life which is carried out in accordance with Islamic tenets, and in contrast to the conventionally and popularly usage "ends justifies the means" Islam cherished transparency in human dealings where the word "means justifies the ends" is the major watchword and acceptable in Islamic world of management.

For example, in conventional management, there are lot of inconsistencies such as cheatings, exploitations, oppressions, hoardings, abuseof man power, intimidations and the likes; all these were being put in place in order to acquire wealth at the expense of others, no matter how people are suffering, "ends justifies the means".

Islamic management on the other hand serves as checks and balances against these attitudes by contrasting and condemning these attitude with reference to them as an act of jeopardy. In support of this, Abbasi et al, (2010) [5]was noted to have opined that, the religion of Islam created a unique management system or pattern that encouraged civility, prosperity, diversity as well as happiness among people of different creeds and ethnics for more than 1000 years. Meaning that, Muslim(s) must be prudent in acquiring wealth by considering others' welfares as our first priority. The prophet says;

"None of you truly believes until he loves for his brother what he loves for himself."(Sahîh al-Bukhârî and Sahîh Muslim)[6]

In this while, man has a duty to develop the earth by making changes to contribute to the betterments of all other creations in the global world especially mankind, since mankind has been considered as vicegerent and the best creation above all other creations. Man thereforepossesses competent capabilities to develop the earth, this process needs a kind of systematic act which can be called 'management'. Abdul Ghafar(2009) [7]quoted the holy prophet to have said:

"God likes the man, which whenever he does things he performed it in the best way".

Looking at some definitions on Islamic management, (Osman andShuhaimi, 2012) [8] concluded that, Islamic Management has to do with involvement in the "various moral norms especially created for humanity and prosperity of mankind", theyfurther explained that, Islamic management is only engaged in a healthy atmosphere that makes goods and services which increase the welfare of mankind. Again, unlike the western or traditional definition of management which is only answerable to the stake or shareholders, Islamic management is involved with a comprehensive, efficient and effective management of all goods and services not only answerable to shareholders but to the society and the Creator.

Islamic management as noted by Abrar (2008) [9] in his article titled:Organizational Development through Islamic Managementis a governance model that provides a positive spiritual dimension to the existing 
management principles for restoring the balance in everyday management decision making processes by mankindwhich centered on good and forbidding what is wrong. It is also considered as an approach for Godconscious professionals which offers a balanced approach of implementation, managing and looking after the sustenance of both personal and organizational roles as well as responsibilities.

This is seen as a model of governance which dealt with the provision of positive spiritual dimensions to the existing management principles to restore balance in human's daily management decision making process which the end result is to enjoin good and forbid wrong for the entire global world. This is because, the current trend of business transaction in the global world is an increased emphasis towards return capital due to the fact that financial profitability and risks associated with material well-being has taken on a central role in business decision making processes since the issue of social justice, public trust as well as civic responsibilities are frequently traded for economic rewards or gains.

Abrar (2008) [10] explained further that, while the religion of Islam is trying to offer the best approach towards eradicating the abnormal conditions of the current society, the western organizational management framework is offering a process oriented approach to manage organizations for achieving effectiveness and inducing efficiencies, in this while, the best approach referred to byAbrar in his explanation is that of Islamic management system organization.

According to him, it is also realized that it's high time to embark on a merging exercise between both ideologies where the Islamic spirituality or ideology will be incorporated together with the western oriented management frameworks, this incorporation is expected to be the new genesis of Islamic management frame work to be known as 'Management by Islam'(MBI).

In the same vein, it is noted by Abrar (2008) [11], thatthe stakeholders are presently evaluating their scorecard in myopical manner, that is, they only focused on year end profits basically meant for yearly evaluation where the performance, quality as well as customers satisfaction are basically viewed in terms of their impact, contributions and efforts to the financial bottom lines, meaning that the only concern of today's business management centered on the year-end profit and loss statements and has considered thisto be the only guiding tools for economic health and performance measures.

Due to this, the issue or application of transparency and accountability are offered by a myriad operational frameworks and management philosophies which have fully tend to be the promise of a greater return on investment at the expense of others. Whereas for a God-fearing and conscious individuals, the major priority in contrast to the philosophies of return on investment (ROI), is to be conducted on the principles of encouraging righteous deeds and forbidding the wrongful acts in their transactions. The typical illustration of this could be found in the sayings of the noble prophet Muhammed (PBUH) as quoted by Abrar Ansari (2008)[12] and Umar FaruqAbd-Allah (2007) [13]thus;

"the essence of the religion of Islam is giving good counseling".

In this while, the issue of counseling urges us tobe a role model for others to follow, where the act modeling is not just a mere verbal lip service(s) or exercise but its relationship is for synchronizing human intentions together with actions. The prophet,as quoted by Ahmed (2008) [14]encourages men thus;

"action shall be judged according to intention".

So, it is clearly seen that, the issue of counseling and modeling is mandatory on mankind at both organizational (public) and individual levels to govern and manage the affairs as a faith-conscious professionals for others to emulate(Abrar 2008) [15].

Moreso, little attention has been given to the Islamic aspects of management as well as its approaches, whereas this Islamic management out passed its contemporaries as noted by Abbasi et al, (2010) [16], that, the religion of Islam created a unique management system or pattern that encouraged civility, prosperity, diversity as well as happiness among people of different creeds and ethnics for more than 1000 years.Although, this had painted the minds of countless mankind such as researchers, leaders as well as managers who followed the idea of convention management system of life as strange.

\section{Islamic Management And Its Objectives}

Islamic management is in the best position to serve the following purposes as its possible objestives on human being:

- Dealing with religious preservation and accountability.

- Balancing equation between the two systems of management that is, the conventional and Islamic systems of management.

- Considering others in whatever we are doing. (life preservation)

- To checkmate means of wealth acquisation. (property)

- To discourage man from any extravagance and illicit act.

- To emphasize the reward for acquisation in both systems. 


\section{Islamic Management And Its Principles}

Like that of the conventional management principles, Islamic 'principles' of management is widely regarded as the fundamental truth, the truth has been stated inform of a cause and effect interrelationship between human being, implying that management principles are the statement of general truth by providing guide to thought and action.

The word 'truth' serves as the guiding pillars in the managerial context, functions as well as solution to problems. This goes in line with the application of sincerity by a leader, because when a leader is undertaking his task or responsibility with sincerity and clarity of mind, he has to ascertain the completion of the task with the best of his ability, since it is considered as the best complement which a leader can render to his organization. This is simply because sincerity is an absolute value in human's life, meaning that, leader's loyalty is one of the major concerns among organizations (Abbasi et al, 2010) [17]. The Qur'an directed thus;

"Say it is Allah I serve, with his sincere (and exclusive) devotion" (Q39:34) [18]

Abbasi et al, (2010) [19] also contributed that; "a sincere effort leads to efficiency and efficiency leads to better performance of an individual".

Furthermore, since the philosophy of 'ends justifies the means' has been strictly frowned against by the ethical standard of Islam, a leader needs to follow the honourable principles of righteousness, equalityand beneficence as stipulated by the Islam.

More so, Muslim philosophers have explored values, ethics and standards of good work as a kind of quality needed in a proper Islamic management (Maqbouleh, nd) [20]. It has also been seen that, one of the fundamentals of management is self and quality control as required by Islamic management which is exemplified by both internal and external controls such as self, family, organization as well as management itself (Maqbouleh, nd) [21]. To support this, Maqbouleh (nd)[22]further states that "as quality control system has its roots in the holy Qur'an many ayas urged people to be righteous and lead by example in order to perpetuate a culture of righteousness" he brought aya 44 of surah Al-Baqara as a reference to this, where Allah says;

"Do you order people to be pious while forgetting yourselves, even though you read the book? Do you not understand?"

\section{General Characteristics Of Islamic Management Principles.}

Since the religion of Islam is widely considered as ever-green, its principles connotes the special features such as universal application, flexibilty, general statement, impacts on human behaviour, relationship between causes and effects, equality in its importance, application in careful and discreet manner and decision making(Swati, G. 2013) [23].

In an elaborate sense, the principles of Islamic management like that of conventional principles are considered to be principle of time and space, that is, it is universally applicable in every situation with the intention of achieving the objectives through a collective efforts. Organisations such as social, political, cultural, religous and media outlet are applying it for the successful operation of their activities(Swati, G. 2013) [24].

Another principle of Islamic management system is dynamism, where Islamic management principles are not static but with dynamic guidelines, simply because, Islamic management is meant to help the business in manifolding its profit at a minimal and reasonable cost. Since the business and its immediate social and economic environment are enough to suit the purposes of its establishment such as size, nature, needs and situations of the business(Swati, G. 2013) [25].

In addition, the principle of Islamic management is a continuous process for its improvements and modifications on the entire Muslim Ummah, it is clearly stated that principles of management is always flexible not rigid. "Management is not a static concept but a dynamic process involving many different skills such as decision making, problem solving, creativity, negotiation and interpersonal relations" (Alan, 2006) [26]. Allah says in the holy Qur'ran thus;

“.... and seek for their opinion on an issue....." (Q3:159) [27]

Moreso, in all ramifications, Islamic principles of management are majorly concerned with human behavoiural activities which can not be tested and determined under a specified, clear cut and controlled condition(s) be it scientific or the likes, since human-beings are created with different characters and diversities, their behavour is unpredictable. For this, management principles are not as exactly as that of physical science principles,management principles are merely general statements (Swati, G. 2013) [28].

Moreover, individual differences is another characteristics where human element is an intergral and essential part, because, its activities and extracts forms other factors. In liue of this, individaul differences (human behavoiur) is now in recognition since every individual works different from each other regarding their ability, knowledge, skill, socio-economic status, attitudes, ideologies and beliefs(Swati, G. 2013) [29]. 


\section{Cause And Effect Relationship}

On the issue of cause and effect relationship, it is indicated that, this relatoinship is needed by the management, for instance, if there is an element of bias in the rating system of staff in terms of salary and allowances (piece-rating), the consequence of this principle is that there will be an increase in the quantity of work but the more the work is higher, the quality of the production will be negatively affected (reduce in the standard). The only way to curb this is for the management to introduce or adopt the principle of unity of command in order to avoid confussion, duplication and overlapping(Swati, G. 2013) [30].

Furthermore, management is the only concerned body to decide on the possible combination of the available resources due to the fact that,factorsof productions are limited and scarce and there is an alternative in it uses. Even most suitable techniques of production need to be decided for proper outcome of result(s). For this illustration, management principles are therefore the basis of decision making (Swati, G. 2013) [31].

To add more, there is no preferential treatment between the principles, that is, the principles of management are of the same standard and equal, no principle has a greater influence or importance than the other, and it is hard to claim that the principles of unity of command is more superb than the principle of unity of direction.

All the principles of management are equally important. Not only that, blind application of management principles is not encouraged, because of the relativity it entails, it is not obsolute. Careful and discreet application should be done in accordance with the organisational needs and situations. (Swati, G. 2013) [32].

\section{Functions of Islamic Management}

Generally, the major task of both management system, that is, the Western and Islamic management is centered on decision making where all important decisions of a given enterprises or business is to be made, it also involved various administrative functions by responsibly framing policies for the smooth running of the organization, human and material resouces, determining the aims and objectives, formulating and taking important business decisions, deciding future course of action by considering policies such as economic, public opinions and other factors at both local and international levels, assemblage of the resources needed for proper planning and issuing guidelines to the employers (Sanket, 2013) [33].

\section{Models of Islamic Management}

It is seen and experienced that the ability to manage and coordinate an organization (human and material resouces) requires a skillful engagement due to the fact that organizations are there to face some challenges.

Every leader, be it corporate (public) or otherwise (private) needs to approach their obligations to fulfill the purpose(s) of establishment. But to bring their dream of fulfillment into reality, how to tackle the obligations and challenges is considered most important obstacle or worrisome exercise for various researchers in the field of business as well as management in general (Abbasi et al, 2010) [34].

Islam as a religion has not left any stone untouched in human's life, it greatly contributed to the managerial aspect of human's life for the betterment of the entire Muslim world bystipulating that,for the leaders in the field of Islamic management to achieve their purpose(s) of establishment, total submission to the 'will' of God is required as stipulated in the divine revelation (Qur'an and Hadith), where every leader is expected to have totally surrenderedhis authority(s) to the divine regulations purposely to gain adequate knowledge and methodological approach to the problems and challenges faced by his organization. To buttress this, Abbasi et al (2010) [35], in their work titled: Islamic Management Model,opined that; "leaders first surrender their authorities to 'divine' instructions and then gain knowledge and practices from those instructions for a holistic approach to organizational management". Abassi et al (2010) [36] put it further that, surrendering ones' leadership post to the divine stipulations instills sense of humility, responsibility as well as selfaccountability in the organizational leader to attain the highest level of expectations, meaning that, they could be able to fulfill their managerial obligations as expected.

In this instance, the holistic or divine system of approach to organizational management by the leaders provides them with more options in settling some issues with the help of innovations and creativity.

Thiswork of Abbasi et al (2010) [37], also introduced Islamic management model as a moderate and lawful model of application to human's daily transactions and later concluded that; "Islamic Management Model is flexible enough to adapt to the circumstances for maximum outcome of the organization" which would help in managing human and material elements in the society.

The model stipulated that, leaders needed to surrender their authority to the instructions encompasses in the divine injunctions from the holy Qur'an and prophetic traditions respectively. In the same work of Abbasi et al, (2010) [38], authority is considered as the power to issue command, given order, make decision etc. And for 
the leaders to fully dance to the tune of embarking on this Islamic model of management there are three major elements to be put in place such as humility, responsibility as well as accountability (Abbasi et al 2010)[39].

There is a popular sayings thus "pride goes before a fail" meaning that 'arrogance' is totally rejected in Islamic managerial or leadership system, for every power belongs to God alone (SWT).He bestowed it on whoever He wants. For this, it is incumbent on a leader(s) to lower himself to the lowest level of humility, because his leadership just comes by chance not by his making, because there are many people better than him and fit-in for the exercise but they are not appointed to serve the purpose.

The most expected exhibition from a leader as stipulated by Islam is to always seek Allah's help to support him in the proper administration for successful outcome of the assigned task.The Qur'an advised the leader to be seeking for support and guidance thus;

"O my Lord! Expand my breast; Ease my task for me" (Q20:25-26) [40],

Unus(2005) [41] also noted that, as a response to Allah's command (humility), Prophet Musa (AS) as a leader, asked for help from his Lord (God) to support and enhance him towards the successful completion of his assignment. His request or plea for help was noted and considered as authentication or approval for every Muslim leader.

This is another aspect which a leader mustexercise for the fact that, the purpose of his appointment is majorly based on responsibility to the people under his tutelage, simply because, responsibility is considered to be the supporting force in binding the courses of action needed for leadership position.

By implication, Islam enjoins leaders to know their responsibilities, watchword, targets, reward-able and non-reward-able actions as well as consequences of mistakes from leader's end. (DeKrey et al., 2007) noted by Abbasi.et al, (2010) [42].

The word responsibility is also considered as a "duty to deal with something so that it is your fault if something goes wrong" (oxford Dictionary, 2007) [43], meaning that, a responsible leader is to stand by whatever happens during the course of his administration and always ready to answer the call of his followers on any matters which request his attention.Kraines (2001) [44],also in support by contributing that, leaders have to deliever all the elements of responsibility. In respect of this, there are series of Qur'anic and prophetic admonitions regarding the issue of responsibility, among them was narrated by the authority of 'Abdullah ibn 'Umar thus;

"whenever God makes a man responsible for other people, whether in greater or lesser numbers, he (a leader) will be questioned as to whether he ruled his charges in accordance with God's decrees or not,and that will not be all. God will question him even about his family members".(IbnHanbal) [45]

As the name implies, Oxford Dictionary, (2007) [46], sees 'accountability as the situation where a leader is expected to give explanation of his action, accountability is generally and widely associated with monetary transactions but in the real sense of it, it encompasses every aspects of administrative exercise, it is more or less the same with the issue of 'responsibility' in Islamic system of management.

Accountability is seen as another sensitive aspect of Islamic management model introduced by Abbasi et al (2010) [47], where the leader must emerge as the best among the people to help him accountable to his people in order to come closer to God as well as the entire society. Fairholm (2001) [48],also contributed that "leaders that emerged as the best in the history are those who knew that they are accountable to their followers" (Fairholm, 2001) [49].

In this regard, a leader must always bear it in mind that it is incumbent on him to account for the deeds in the presence of his people and his Creator, that whatever he sows shall be reaped and if a leader wants his name to be immortalize for goodness or otherwise, the level of his accountability will be its determinant. Abassi et al, (2001) [50] observed that "accountability conveys an image of trustworthiness".

In lieu of this, "accountability has become an icon for good leadership performance both in the public and private sectors" (Bovens 2005) [51]. But aside the human or scholarly support in the area of accountability in Islamic management realm, there are also series of divine injunctions which served as reminder, warning, admonition etc about the gravity of accountability in Islamic system of management. Qur'an says;

"then shall anyone who has done an atom's weight of good, see it! And, anyone who has done an atom's weight of evil, shall see it". (Q99:7-8)[52]

\section{Management Activities During The Early Days of Islam}

In order to appreciate and authenticate the work of Abassi et al, (2010) [53] on the above subject matter, there is the need to appraise the management system implemented by the holy prophet of Islam (PBUH) while alive, since he hadbeen considered as the noblest in character which every Muslim must emulate for his goodness, humility, accountability, responsibility and many more.

This served as a starting point for the entire Muslim world to emulate and abide with, because its establishment during the early period of Islam by the holy prophet (PBUH) enriched its wider acceptability through gradual processes. This led many scholars in the field of science to focus their scholarly works on 
Islamic management system of living. This according to Nasri\&Nazemi(2012) [54]is "the management system that was initially established by prophet of Islam enhanced its enrichmentlittle by little, and then many Islamic scientists focused occasionally on management from Islamic point of view....".

Scholars such as FarabiAbu Nasr wholived around 920-300 after the emergence of the religion of Islam, EbneKhalidunwho lived around 950, Avesina or IbnSinawho lived around 550 years of Islam and a host of others were those who carried out a great and precious job towards the invention of Islamic system of management. (Nasri\&Nazemi2012) [55].

FarabiAbu Nasr (920-300) [56],presented some ideas concerning the issue of management and organization, where he categorically indicated that an ideal society was the most needed environment for the generality of mankind and that, this type of society was considered to be an avenue where the relationship between the members majorly centered on justice as well as an ideal leader to direct the affairs of the community. He later gave a recommendation that, the type of society mentioned above deserved a leader of high adequate and acceptable characteristics to control the affairs.In addition, Taghavi, (1985) [57], further identified that,EbneKhalidun (950)also discussed the necessary procedures of ruling and governing, as well as method of handling the management activities among different communities or environments from three major perspectives such as habits, behavior and civilization.EbneKhalidun later confirmed that, in any given society, the residents need a leader, ruler or sovereignty to protect them against violation and aggression (Taghavi, 1989) [58].

Furthermore, a popularly known scientist, Avesina or IbnSina in his article titled: 'KitabolMajmoo', also contributed to the issue of fundamentals of government together with the management style, that both pattern of management as well as method of appointing a leader are mostly important criterion to determine the management activities of any society, where he later identified totalitarian, democracy, oligarchy and humblest as four types of government from his own idea (Motahari, 1997) [59].

Looking critically at the opinions of the three different scholars mentioned above, it is clearly seen that, all their ideashave been developed on by the western philosophers like Plato and others (Taghavi, 1989) [60].

Nasri\&Nazemi (2012) [61], noted two major points out of the above scholarly ideas towards establishing an Islamic management system, the first is considered by them as management itself, elements and its improvement, while the second one is in the aspect of the environments or organizations which the management has taken place during the early period of Islam and the categories of people that handled the management of the period. In this case, Nasri\&Nazemi, noted that, "the scholars have all considered country, state and territory as organizations and rulers, governors and army commanders as managers".

Moreso,this management system continues till the period of industrial revolution in Europe, when the Muslim experts as well as scholars slept off their effort of research, theorizing, modeling towards the improvement and progress of Islamic management system of life, this gave opportunities to the Westerners and European scientists to access the great job being carried out for long by the Muslimexperts.

The Europeans quickly acquired it and made a great and rapid transformation of the works of the Muslim experts by westernizing and claim the original ownership of the source, ideas and materials. This transformation was rapidly done to the extent that, the assignment which consumed a thousand years of the Muslim experts, as supported by Abbasi et al (2010) [62], bythe religion of Islam which created a unique management system or pattern that encouraged civility, prosperity, diversity as well as happiness among the people of different creeds and ethnics for more than 1000 years, were just carried out within just one and half century by the Westerners.(Nasri\&Nazemi, 2012) [63].

However, in the current time, the major priority of the entire world, be it Islamic or not among the countries all over the world is concentrated on the issue of development and progress where the developed countries are agitating to become post developed i.e post industrialization and modernization, developing countries are working towards becoming developed, while the under developed are struggling to become developed. In this instance, it is certain that, the determinant of the progressive and successful outcome of these countries are methods, patterns as well as organizational system of managing the society, which comprises of both public and private enterprises.

More so, the managerial exercise or reflection of a country(s) effectively contributes to the possible development of the society,Motahari (1997) [64], supported that; "the most important criterion for classification of governments is the pattern of management and the method of selecting or appointing the manager". (Nasri\&Nazemi, 2012) [65].

In the present world, some countries had tailored their management systems towards the expectations of the religion of Islam. When it comes to the issue of Islamic management activities, countries like Iran, Saudi Arabia, Malaysia to mention but a few are notable of this practice. Nasri\&Nazemi (2012) [66] described this as, "..some countries in the worldtending to achieve their goals of using a kind of management pattern called Islamic management system (IMS)". 
These countries are trying to unveil the importance of managing a society in accordance with the divine stipulations by show-casing the true picture of Islamic heritage on the entire Muslim world.

Moreso, decision making, assemblage of the available resources and issuance of guide lines as seen in the functions of management can only be implemented by humanbeings in every industry, particularly in an Islamic environment. To buttress this, Taghavi (1989) [67], confirmed that "people in any society need a ruler or sovereignty that protects them against violation and aggression".

\section{Conclusion}

Management in human's life cannot be handled with levity since it has occupied the major life of the entire populace, for its provision of adequate managerial skill in utilizing the natural endowment for the promotion and development of humanity aimed to bring total changes in the peoples' life style.

And since management is an entity, it cannot work alone without the support or supervision of human effort(s), this effort needs to be incorporated in order to benefit from what Allah (SWT) has provided for human consumption. Humanbeing as a manager (vicegerent) is in the best position to manage all the endowments and adequately apply the principles in line with their managerial exercise.

Decision making, assemblage of the available resources and issuing of guide lines as seen in the functions of management can only be implemented by humanbeings in every industry, particularly in an Islamic environment.

Not only that, the main motive of establishing a business in Islam is for profit generation, to please the stakeholders, the society and the Creator (Allah).Humanbeing as the, investor, supervisor, manager or head in an environment of Islam is to manage it well to achieve the desired goals by providing qualitative services for the society as a fulfillment of its social responsibility and to generate income for the business owner and at the same time be accountable to his or her Creator without biases or hindrances.

Islam teaches moderation and consideration, all these must be manifested in a faithful one to determine the level of his obedience to Allah and His messenger (PBUH), whoever turns against it has done otherwise. Since the act of managing has been decreed by Allah (SWT) and His apostle (PBUH), it has been promised that whoever stricts to what has been ordained by Allah (SWT) shall be greatly rewarded and whoever transgressed shall also be greatly rewarded on the other way round (punished).

It has been established in the traditions of the Holy prophet (SAW) that extravagant dealings was discouraged for mankind, particularly the Muslims, his discouragement on this has served as a lesson for his followers, current generation and generations yet to come. Allah says to the holy prophet thus;

"Verily, you are of the noblest of character. "(Q68:4) [68] .

With the above illustrations, every leader is considered as a role model for its followers to emulate as a systematic way of living which could later transform into cultural norms of a given society. Abbasi et al, (2010) [69], noted that "organizational cultures/members are influenced by the leadership of an organization. Jabnoun (1994) [70], supported that "leaders are considered as role models and that their behavoiur is reflected on the culture and procedures of the organization". The Islamic management system is hereby recommended for every nuclear and big organization to enable people have access to socio - economic justice.

\section{References}

[1]. Abbasi, A. S. et al, 2010. Islamic Management Model. African Journal of BusinessManagement Vol. 4(9).

[2]. Anupam, K. \&Bidisha, D. 2012. Principles and Practice of Management and Business Communication.Published by Dorling Kindersley (India) Pvt. Ltd, licensees of Pearson Education in South Asia.

[3]. Alan B. A, 2006.Management of Electronic Media, Third Edition, Publisher: Holly J. Allen, Thomson Higher Education, Belmont, USA.

[4]. SanketKhandkar, 2013. Management Objectives:www.publishyourarticles.net/knowledge-hub/business-studies/managementobjectives.html. 23/02/13.

[5]. Abbasi Ibid.

[6]. Sahîh al-Bukhârî and Sahîh Muslim.

[7]. Abdul Gafar, H. D. 2009. Knowledge Management and its Impact on Islamic Da'wah: A Historical Perspective, Journal of Islamic and Arabic Education 1 (2).

[8]. Osman C. A \&Shuhaimi H.I 2012. Conceptual Frame work of Good Management from the Islamic Perspective: International Journal of Business and Management Studies vol 4, No 1, ISSN: 1309-8047.

[9]. Abrar, A. 2008. Organizational Development through Islamic Management Frameworks.Management by Islam (MBI).www.managementbyislam.com. Retrieved on 22/05/13.

[10]. Ibid

[11]. Ibid

[12]. Ibid

[13]. Umar FaruqAbd-Allah, 2007. Living Islam with Purpose.AnNawawi Foundation Paper.Accessed on 21/04/14

[14]. Ahmed, 2008. Deeds Are According To Intentions. www.haqislam.org/deeds-are-according-to-intentions/. Accessed on 21/04/14

[15]. Abrar Ibid

[16]. Abbasi, A. S. et al, 2010. Welfare and Protection Model for Organizational Management: The Islamic Perspective. African Journal of Business Management Vol. 4(5).

[17]. Ibid 
[18]. Al-Qur'an

[19]. Abbasi Ibid.

[20]. Maqbouleh M. H (nd), Islamic Values and Management Practices: Quality and Transformation in the Arab World. www.gowerpublishing.com/isbn/9781407522. 1/3/13.

[21]. Ibid.

[22]. Ibic

[23]. Swati Gupta, 2013. Definition, Meaning and Characteristics of Principles of management: http://www.publishyourarticles.net/knowledge-hub/business-studies/principles-of-management.html. 23/02/13

[24]. ] Ibid

[25]. Ibid

[26]. Alan Ibid.

[27]. Al-Qur'an Ibid

[28]. Ibid

[29]. Swati Ibid

[30]. Swati Ibid

[31]. Ibid

[32]. Ibid

[33]. SanketKhandkar Ibid.

[34]. Abbasi, A. S. et al, 2010. Welfare and Protection Model for Organizational Management: The Islamic Perspective. African Journal of Business Management Vol. 4(5).

[35]. Ibid

[36]. Ibid

[37]. Ibid

[38]. Ibid

[39]. Ibid

[40]. Al-Qur'an Ibid

[41]. Unus, I. 2005. The Story of Musa and Harun: Lesson in Leadership, International Institute of Islamic Thoughts, Herndon.

[42]. Abbasi Ibid.

[43]. Oxford Student's Dictionary, 2007. Oxford University Press, United Kingdom.

[44]. Kraines, G. A. 2001. Accountability Leadership: How to strengthen Productivity Through Sound Managerial Leadership. Franklin Lakes, NJ: Career Press.

[45]. IbnHanbal

[46]. Oxford Student's Dictionary Ibid.

[47]. Abbasi Ibid.

[48]. Fairholm, G. W. 2001. Mastering inner leadership. Westport, CT: Quorum Books.

[49]. Ibid.

[50]. Abbasi Ibid

[51]. Bovens, M. 2005. Public Accountability: A Frame work for the Analysis and Assessment of Accountability Arrangements in the Public Domain.

[52]. Al-Qur'an Ibic

[53]. Abbasi Ibid.

[54]. Nasri, F. \&Nazemi, M. 2012. Islamic Management System (IMS): Past, Present, Future. Journal of Islamic Finance and Business Research.Vol. 1.No. 1

[55]. Ibid

[56]. Farabi Abu Nasr 920-300.The Principles of the Views of the Citizens of the Best State'.Revised text with translation and commentary by Richard Walzer.Published by Oxford University Press, USA (July 25, 1985).Accessed on 20/02/13

[57]. Taghavi, R. 1989. A Review of Islamic Management, Publishing by the Organization for Islamic Propaganda, Iran

[58]. Ibid

[59]. Motahari, M. 1997. Islam and Iran Counter Services, $8^{\text {th }}$ Edition, Sadra Publishing CO. Tehran, Iran.

[60]. Taghavi, Ibid

[61]. Nasri\&Nazemi Ibid

[62]. Abbasi Ibid

[63]. Nasri\&Nazemi Ibid

[64]. Motahari, Ibid

[65]. Nasri\&Nazemi Ibid

[66]. Ibid.

[67]. Taghavi, Ibid

[68]. Al-Qur'an Ibid

[69]. Abbasi Ibid

[70]. Jabnoun N. 1994. Islam and Management, Institute KajianDasar (IKD). 